\title{
Kalighat, the Home of Goddess Kali: the Place Where Calcutta is Imagined Twice: a Visual Investigation into the Dark Metropolis
}

\author{
by Erica Barbiani \\ University of Urbino \\ Sociological Research Online, Volume 10, Issue 1, \\ $<$ http://umw.socresonline.org.uk/10/1/4.htm/> \\ doi:10.5153/sro. 988
}

Received: 28 Sep 2004 Accepted: 7 Dec 2004 Published: 28 Feb 2005

\begin{abstract}
The identity of Calcutta has often been associated with the goddess who gave the city its name: Kali, the black divinity of death and destruction. Many examples of this imagery can be found in literature, where the Goddess and her myth are used as a metaphor to describe Calcutta. The deathly and violent connotations of Kali are extended to the city, which is depicted as a 'metropolitan nightmare', a place identified with overpopulation, poverty, political riots and sickness. Goddess Kali -the city's symbolic ideal-type - was used as an entry point to investigate certain aspects of Calcutta's negative imagery with visual methods: the abstraction of the metaphorical link between goddess and city was transposed by photographs and video to their concrete, contemporary urban space. Images produced on the icons of Kali around Calcutta, on the temples dedicated to the Goddess and on the rituals made in her honour will show the spatial embodiment of the Kali/Calcutta link and its deep relation with colonial history. The adoption of visual methods enhanced the peculiarity of the Kalighat neighbourhood, the place where Mother Teresa's Hospital of the Dying Ones stands back to back with Goddess's Kali most ancient temple and icon. Kalighat is not only the historical site where the symbolic link between city and goddess was developed, but also the place where the dark narrative is kept alive.
\end{abstract}

\section{Keywords: $X x$}

\section{Introduction}

1.1 There is a saying among 'western' foreigners who travel to India: "Go to Bombay for fun and move to Delhi to extend the visa, but try to avoid Calcutta if you do not have an inclination towards voluntary service" (Barbiani, 2002). The negative reputation commonly attributed to Calcutta can not only be found in the interactions of 'western' travellers, but it is inscribed in a rich body of literary and scientific texts. The 'west' frequently pictures Calcutta as a scary urban setting, dominated by overpopulation, poverty and disease. Even if such negative connotations are attributed to other former colonies and "undeveloped" metropolis, Calcutta stands out as the archetype of the metropolitan nightmare described with accuracy by Moorhouse in the book Calcutta, the City revealed (Moorhouse, 1971: 18). There are two specific elements that characterize the negative imagery of Calcutta and that make it an interesting subject of investigation:

1. The city's imagery is directly associated to a local religious icon: goddess Kali. Texts quoted in the following sections will in fact show how the goddess known in the 'west' as the black divinity of death and destruction is often referred to in literature as a metaphor of the city's negative traits.

2. The history of the city: there was no Calcutta before 1690, date of the British arrival in Bengal. The former British Empire capital was just a swamp with few settlements in pre-colonial times: the city and its imagery are an imperial creation.

1.2 Starting from the historical and symbolical link between Kali and Calcutta this paper discusses the adoption of visual tools leading to a wider understanding of the city as contemporary urban space. The point is not trying to understand why Calcutta has a bad reputation or what role colonial culture played in shaping it, but rather observing contemporary urban space through the lens of a particular relationship between the city and her patron Goddess. We can study the different cultural vehicles and how they become actors in the construction of a city's imagery: movies, people's interactions, news reports, advertisements and literary works are only some of the ways in which urban narrative is constructed (Griswold, 1994). Architectural facades, historical events and anecdotes mingle together and contribute to build an abstract image of the city (Lynch, 1960), but can we walk this path backwards? Can we look for the physical 
elements that embody a specific city narrative and capture them with photographs or video (Lash and Urry, 1994)? If we apply the theoretical framework of constructivism backwards, we could attempt to translate the abstraction of a city's imagery into photographs and videos made especially for its representation and exploration.

1.3 The research project referred to in this paper aimed at investigating the negative metaphorical link between Kali and the city using qualitative methodology that integrate the use of visual tools (Barbiani, 2002). The choice of the term integrating is pivotal since the production of images was one of the methods adopted in a wider qualitative methodology, coupled by other research tools such as interviews, analysis of literary texts, anthropological and historical data (Prosser, 1998).

1.4 Among these tools, the visual methods best transposed the Kali/Calcutta imagery from the abstract level of literary analysis to the concrete level of urban space. As in the research process itself, the literary and historical associations between the goddess and the city will become more and more "grounded" in urban locations.

1.5 Visual research stressed the importance of the Kalighat neighbourhood: the place where the most ancient Kali temple stands back to back with Mother Teresa's Hospital of the Dying. Far from being a historical and religious vestige Kalighat is still the favourite current location of a long lasting dialogue between 'local' and 'western' culture: this is the place where the negative link between Kali, Calcutta and 'western' presence in the city is kept alive.

\section{The Kali/Calcutta Imagery}

Some places are too evil to be allowed to exist. Some cities are too wicked to be suffered. Calcutta is such a place. Before Calcutta I would have laughed at such an idea. Before Calcutta I did not believe in evil, certainly not as a force separate from the actions of men. Before Calcutta I was a fool.

After the Romans had conquered the city of Carthage, they killed the men, sold the women and children into slavery, pulled down the great buildings, broke up the stones, burned the rubble, and salted the earth so that nothing would ever grow there again. That is not enough for Calcutta. Calcutta should be expunged. Before Calcutta I took part in marches against nuclear weapons. Now I dream of nuclear mushroom clouds rising above a city. I see buildings melt in lakes of glass. I see paved street flowing like rivers of lava and real rivers boiling away in great gouts of steam. I see human figures dancing like burning insects, like obscene praying mantises sputtering and bursting against a fiery red background of total 
2.1 This quote is taken from the introduction of the novel "The Song of Kali" and the explicit reference Kali in the title is not coincidental. The fictional work of Dan Simmons is a perfect match with a literary trend describing Calcutta with deathly and negative qualities, by associating it with its patron divinity Kali. With the sentence 'a place too evil to be allowed to exist', Simmons articulates 'western' dismay with the city. Geoffrey Moorhouse's (1971:18), sociological essay on Calcutta describes the city as a "metropolitan nightmare" and clearly portrays it with dreamlike qualities as a grotesque and violent caricature. His deathly view of Calcutta compares it to the goddess Kali and says, "The very name of Calcutta is derived from a symbol of fear and evil" (Moorhouse, 1971: 20). There is some truth in his statement: if we take into account the most common interpretation ${ }^{[1]}$, goddess Kali has provided the city's name: Calcutta comes from the old name Kali-khata, which means City Of Kali .

2.2 Kali, who has been Calcutta's patron divinity since its founding, is the Hindu goddess of death. She is portrayed with black skin ${ }^{[2]}$, a garland of skulls round her neck, a sharp sickle in one hand and a beheaded figure in the other. She is the goddess known for claiming human sacrifice during nights of a new moon in the Bengal jungle. She features in novels by Salgari and Kipling, and in movies such as "The mystery of the Black Jungle"(1955) or "Black Devils of Kali" (1956) set in the jungle of Bengal where young blond women in colonial outfits were chased by the devotees of a the murderous goddess. The relation between the goddess and the city is articulated in numerous literary works: the murderous Kali and the life ridden overpopulated Calcutta mirror each other, Calcutta the urban body of the goddess, Kali its attitude, its psyche, with the city name bearing the assonance of her patron goddess. But who set the boundary of the imagery where Kali and Calcutta are metaphor for each other?

\section{Historical Traces: The Temple of the Black Jungle}

"There is no peace in Calcutta

blood calls at midnight"

Sukanta Bhattacharjee (Simmons, 1985: 178)

3.1 Delhi, Bombay and Madras were already fully developed cities when the British arrived in India. However, the territory chosen by Job Charnock - colonialist of the East India Company - for the foundation of Calcutta was nothing but bog, jungle and quicksand. In 1690, on a land inhabited nowadays by about 15 million people, there were only three small villages that were built near a salt lake and a small temple Kalighat - dedicated to the Goddess Kali, who was very popular in Bengal.

3.2 The salt lake flooded frequently and the rotten fish left by the receding waters caused cholera and malaria. In the first fifty years of British settlement, a third of the colonists died for the poor sanitary conditions. Back home, in London, the newborn Calcutta went by the name of "Charnock's folly, the chance erected city" and there were puns on the assonance between Calcutta and Golgota - land of the skulls (Chaudhuri, 1990).When the colonialists arrived in 1690, there was no resistance by the autochthonous population. The only forbidden territory was that of Kalighat, the most ancient temple of Kali in India. But this prohibition was anyway redundant, since the rituals in honour of the goddess were repellent for the colonialists. A thick jungle surrounded the temple and the main worship took place after midnight of a new moon and goats were sacrificed. Night worship was a strong taboo for the Christian cultural background of the colonialists. The relationship between the colonialists and Bengal was unusual compared to other well established cities in India. In terms of the colonizers' values Bengal was wilder and less civilized; the East of the Indian subcontinent was perceived as a particularly dangerous and unknown frontier. It was not as much a land of cities to be occupied as a land where cities had to be built.

3.3 This is the historical draft of two images that start to overlap: the unhealthy newborn Calcutta and goddess Kali, whose religious and cultural heart throbs in the Kalighat shrine. The decimation of the colonialists through disease is slowly associated with strange night rituals that take place in the temple. Frightening stories of memsahibs (white madams) sacrificed to the goddess begin to circulate. The novelist Kipling wrote a poem about Calcutta titled "The city of dreadful nights ":

Thus the midday halt of Charnock - more's the pity!

grew a city

as the fungus sprouts chaotic from its bed

so it spread

Chance-directed, chance-erected. Laid and built

on the silt

Palaces, poverty and pride-

Side by side: 
and, above the pestilential town

death looked down.

(Kipling, 1890)

3.4 There is little positive literature on Calcutta as one of the most artistically and intellectually active cities in the world (Hannerz, 1983): at the time of Bengali Renaissance (1772-1857) the metropolis was avantgarde in civil rights with respect to India and Europe. When Calcutta was the capital of the British Empire from 1877 to 1911, it was the only city in South Asia with a university (Hannerz, 1983).

3.5 Although the seed of the "deathly city" had always been latent in Calcutta - given the interaction between 'western' presence, local cults and the inherent difficulties in building up a city anew - such imagery exploded only after Indian Independence in 1947. Calcutta, one of the most flourishing cities of South Asia at the time, was deeply influenced by the political events that led to the Partition between East and West Bengal. The city was suddenly separated from its geographic hinterland and millions of Hindu people who lived in Bangladesh, formerly East Pakistan, migrated to Calcutta. The sudden departure of the British after World War II had an enormous affect on the city's economy, since the colonialists were deeply involved in local trading activities. It is an oversimplification to call the British colonialists and Calcutta a colonial city, since the city developed and flourished through the interaction between local populations and newcomers. The city is moulded by this double presence: if Kali can be seen as Calcutta's symbolic mother, then the 'west' should not deny its paternity -or step motherhood - as we will see.

\section{Methodology: Visualizing the City's Imagery: Methodological Notes}

4.1 Of the many elements that contribute to a city's imagery, literary works are probably the most powerful. Written work - whether fiction, essays, or poems - are able to construct and circulate lasting images of a city, especially bestsellers such as Dominique Lapierre's ${ }^{[3]}$ "The City of Joy". Writers choose their metaphors from a well of cultural images recognised by their readers.

4.2 As far as Kali is concerned, the rich symbolism associated with the goddess not only makes her a fruitful topos for the description of Calcutta, but also a good Weberian ideal-type with which to explore the city. Researching Kali is a way of gathering information about Calcutta.

4.3 After choosing Kali as the starting ideal-type, the next methodological step was the individualization of a list of analytical macro-categories that, as "sub-idealtypes", distinguished different ways in which Calcutta was associated with Kali. This first short list was sequentially elaborated into a shooting script: every analytical category was extended to a set of questions aimed at getting more detailed information about specific associations between the goddess and the city. Shooting scripts are a methodological tool adopted by grounded theory (Suchar, 1997) and which guide the production of images by limiting and directing the observation of the sociologist-photographer. Taking pictures is, of course, an extremely subjective process, but pictures can not be taken of just anything that is considered connected to the research, as Harper states: "I repeated as a mantra that pictures should be produced with an image in mind" (Harper, 1988: 54).Breaking the complexity of the imagery Kali/Calcutta into a set of sub-ideal types focused - at least partially - the production of images. It is much more useful to investigate the parallel between the goddess and the city by identifying the specific ways in which they are associated instead of attempting to portray the intricacy of their relation as a whole.

4.4 Six categories were constructed in the research, but this paper takes into account only two of them ${ }^{[4]}$ : Kali in the City (A) and The City of Dreadful Nights (B). A literary excerpt introduces the sub-ideal type of a particular association between the city and the goddess for both categories. The short shooting script that follows contains the questions that guided the image capturing process.

\section{Kali in the City}

4.5 The truth is that everything popularly associated with Calcutta is highly unpleasant and sometimes very nasty indeed. The very name of Calcutta is derived from a symbol of fear and evil. Kali appears with devilish eyes, with a tongue dripping blood, with snakes entwined around her neck, or with a garland of skulls. She is Kali the terrible and she is propitiated daily with sacrifices, as well as with flowers. Calcutta, indeed, is a mighty terrible and frightening place today (Moorhouse, 1971: 19-20).

4.6 Calcutta resembles Kali in many ways. Kali the Terrible, worshipped by million of devotees, icon of fear and death, portrayed with a terrific glance, a necklace of skulls around her neck. Many murals proclaim the failure of the city: "there is no more hope here, nothing is left but anger". (Lapierre, 1984:178)

4.7 As Moorhouse and Lapierre claim, Calcutta resembles "Kali the Terrible". India is known for its polytheistic religion, so why is a single goddess taken as a metaphor for the whole city? How is Kali visible 
in the city? Which temples are the most visited in the city? Where are they located? This category was aimed at producing images that documented the location of Kali's icons and temples in the metropolis.

\title{
The City of Dreadful Nights
}

\author{
Kali puja announced, I saw Calcutta \\ descend on us. Three thousand slums, \\ usually rapt in themselves, crouched low \\ by walls or sewer water, now all \\ ran out, rampant, beneath the new moon, \\ the night and the goddess on their side.

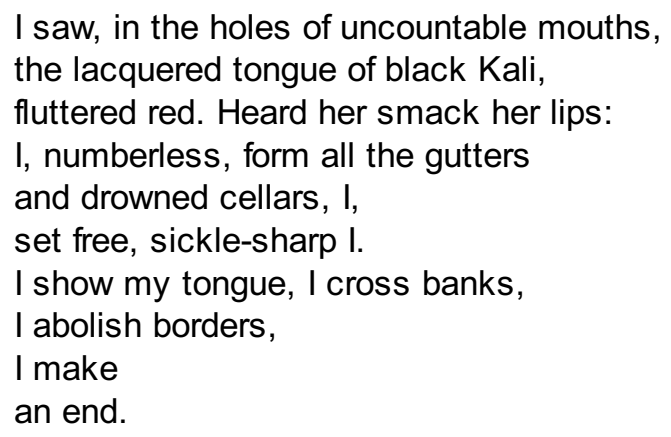

(The festival in honour of the black divinity, said the Telegraph, took place

without incident.)

(Grass, 1989: 146)

4.8 Many literary works describe the dreadful new moon nights dedicated to the worship of the goddess (Grass, 1988;Kipling, 1890;Salgari, 1954;Simmons; 1997): the name of this section is taken in fact from the title of a short story written by Kipling. The poem above by Gunter Grass is an example of this because it describes the city during the night of Kali Puja: the most important new moon night for Kali's cult. "The festival in honour of the black divinity took place without incident, " writes Grass, as if he wanted to underline that this is not what normally happens. What happens during Kali Puja? What is so frightening about it?

4.9 Taking images of Kali's icons, and filming the main temples of the goddess during Kali Puja involved a deep immersion into Calcutta's urban space. The "shooting scripts" channelled attention to potential images, providing an "image in mind" (Harper, 1988: 54) with which to navigate the city's space. Like a questionnaire, shooting scripts focus the attention of the photographer on certain aspects of social life, dismissing others that could also be equally relevant. The goal is not to produce objective representations of reality as much as find a way to partially channel subjectivity and attempt to build a narrative along with it. The following sections will provide a small selection of the images recorded along with the main observations they prompted.

\section{Calcutta: The City of Kali}

5.1 The sequence of photographs shown alongside portrays some of the icons of Kali taken in temples and public spaces around the city. Sound was added to sequences to help render the images in a more "phenomenological way" (Harper, 1988). Sound grounds the flow of images through sensory enhancement. The song was written by a local band called Bhoomi and it is a composition based on a traditional Bengali song and a live recording of street voices of Calcutta.

5.2 These are the three main observations that were prompted by taking the pictures:

1. The icon of Kali and the hundreds of temples erected for her worship outnumbers the presence of other divinities, with respect to other polytheistic cities in India. Since the photographer's eye - mine in this case - was mainly focused on portraying Kali's icons, all the other gods and goddesses were not taken into account. However, it was photographing Kali's sites and 
icons around the city that made me aware that she was effectively outnumbering other gods/goddesses. I started to interview people on this topic, asking if Kali could be considered the most popular goddess in Calcutta and every local person I spoke to agreed that Kali was the most worshipped divinity in the city and that Calcutta could legitimately be considered "The city of Kali". In the sequence of images shown above, the icon of Kali is portrayed on cars, tiles, murals, calendars and in grocery stores. This persistent presence of Kali in Calcutta might be a practical reason for the fact that literary works use the goddess very often as a city symbol. More importantly, the overwhelming presence of Kali in Calcutta draws away from Hindu polytheism: there are no other cities in India so closely associated with a particular god or goddess. This may have been the result of two centuries of western presence in the city: the predominance of a single divinity could be seen as the autochthonous way of replying to the monotheism of the colonialists. However, it could also be indicative of local cults in Bengal prior to British occupation. Contrary to other parts of India that had been already colonised, the Kali cult in the Bengal area already predominated over the worship of other deities.

2. The icon of Kali is used as a protective symbol: taxi drivers fix it in the front of their car to protect them from accidents.

3. Representations of the goddess are not univocal: it carries different meanings in local culture. By observing Kali's presence in cars and taxis, a relevant interpretation stands out: Kali is considered a protective goddess. This quality of Kali is practically unknown in the 'west' where the goddess is remembered only for her bloody and destructive side and her passion for human sacrifice.

In Hindu mythology (Swami Jagadiswarananda) Kali is known as the goddess who helped the gods destroy the devils in their battle against the forces of evil. Kali was the only divine force able to win this battle, and for this reason she is considered a beneficial and protective goddess. Moreover, she is seen as a symbol of how destructive energy should be kept within safe borders. In some versions of this myth, Kali is so intoxicated by her destructive fury that she looses the ability to distinguish between what should be saved and what should be destroyed. She becomes suddenly aware that she has lost this ability when she steps on the body of her beloved, Lord Shiva. This is why she is portrayed with a foot over her lover in anthropomorphic iconography. Her story is a story of beneficial destructive energy and boundaries, but she is generally, simplistically, known as a slayer goddess in the 'west'.

4. There are two representations of Kali in the city, an anthropomorphic, figurative one, and an animistic one: in this second case the goddess is represented with a simple black stone with three red dots and a big tongue. There is only one temple where the animistic iconography of the Goddess is present: Kalighat, the most ancient temple in the city. There are two ways of representing Kali: the first one is described above, taken from the myth where the goddess is shown with her foot over the body of Shiva, the second bears only a slightly figurative resemblance. This second representation, where a black rock with three red dots (the eyes) and a tongue stands for Kali, is the way the goddess is portrayed at Kalighat ${ }^{[5]}$, her most ancient temple. This animistic image of the goddess, although portrayed in devotional posters all around the city, can be found exclusively in Kalighat, while the other hundreds of Kali temples in the city show an anthropomorphic representation of the goddess. This distinction makes Kalighat stand out as a particular location for Kali's cult in the city.

\section{Kalighat/Dakshineswar: Kali Puja in the City}

QuickTime and an MPEG-4 Video Decompressor are needed to see this picture 6.1 Kali Puja night is the most important new moon night of the year dedicated to the worship of Kali. All over the city local people build pandals, simulated temples made of bamboo erected especially for this celebration. Pandals are similar to some carnival-like installation, since each of them is built on a theme, a motive, or is inspired by a specific atmosphere. The two videos included below, portray the two most important temples of Kali in Calcutta and the pandals located in their immediate surroundings. Kalighat and Dakshineswar, in fact, are the two most frequented temples of Kali during the night of Kali Puja. Kalighat, mentioned before as the temple accommodating the most ancient icon of Kali, is located in the centre of the city and it is the most ancient devotional site in the metropolis. Dakshineswar, built in 1847 and located at the northern outskirts of the city, became famous for the activity of the priest Ramakrishna, a mystic and philosopher well known in India and the 'west'. It is interesting to note how the atmosphere of Kali Puja is totally different in the two temples and in their immediate surroundings.

6.2 As far as Kalighat is concerned, the pandals around the temple are inspired by a kitsch representation of death: the video shows an installation whose theme is an earthquake. There are plaster statues of dead bodies about to be burned in the incinerator chamber and fake funerary pyres. In the adjacent pandal there are some blinking Kali robots with skeletons similar to Halloween characters, which seem to mock death. The inside of the temple is chaotic, people push each other attempting to see the ancient icon of Kali, the atmosphere is charged and tense, there are people screaming and crying. During the night about 
120 goats are guillotined and film recording is not allowed around the sacrificial area since it is considered the most sacred.

6.3 The Kali Puja looks completely different at Dakshineswar. The first images included in the video portray a pandal built in the immediate surroundings of the temple. The structure and the interiors of the pandal are decorated in white. The black goddess stands elegantly in the middle, worshipped quietly by the people passing by. Inside the temple of Dakshineswar, big crowds of people are kept orderly in queues and the event is monitored by closed circuit surveillance that shows the rituals. No sacrifice has taken place in Dakshineswar since the end of the 19th century: people circle around the old sacrificial site and put candles and incense around the guillotine.

6.4 The different ways in which Kali Puja night is celebrated in the two temples depends partly on the different class status of the devotees. Kalighat attracts low caste people who cannot afford the trip to Dakshineswar, since the temple is situated in the northern outskirts of the city. Furthermore, middle class people feel uncomfortable going to Kalighat, since it has a reputation for being a chaotic setting where pickpockets thrive. Comparing the two temples, Kalighat seems to better embody the "deathly Kali/dreadful Calcutta" narrative. It is the only temple where goats are still sacrificed, people scream and shout in front of the icon of Kali, all the pandal installations around the sacred area are focused on the theme of death and the roads around the area are poorly lit. All these aspects are absent in Dakshineswar where people wait for hours to see the image of Kali in orderly queues. There are no other temples in Calcutta as peculiar as Kalighat: the oldest temple of the goddess is particularly well suited for the dark imagery of the city quoted in 'western' literature.

\section{Kalighat/Hospital of the Dying: The Two Mothers Living Together}

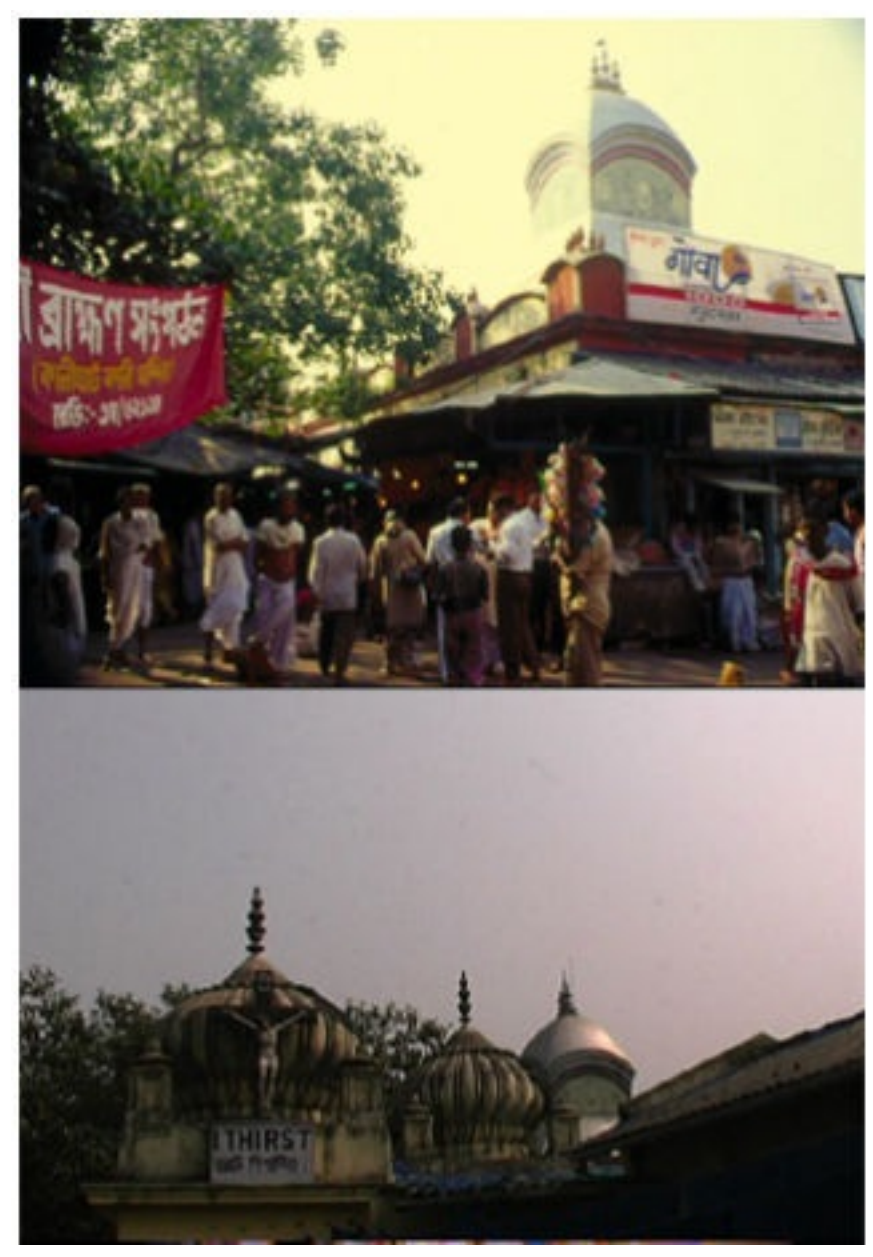




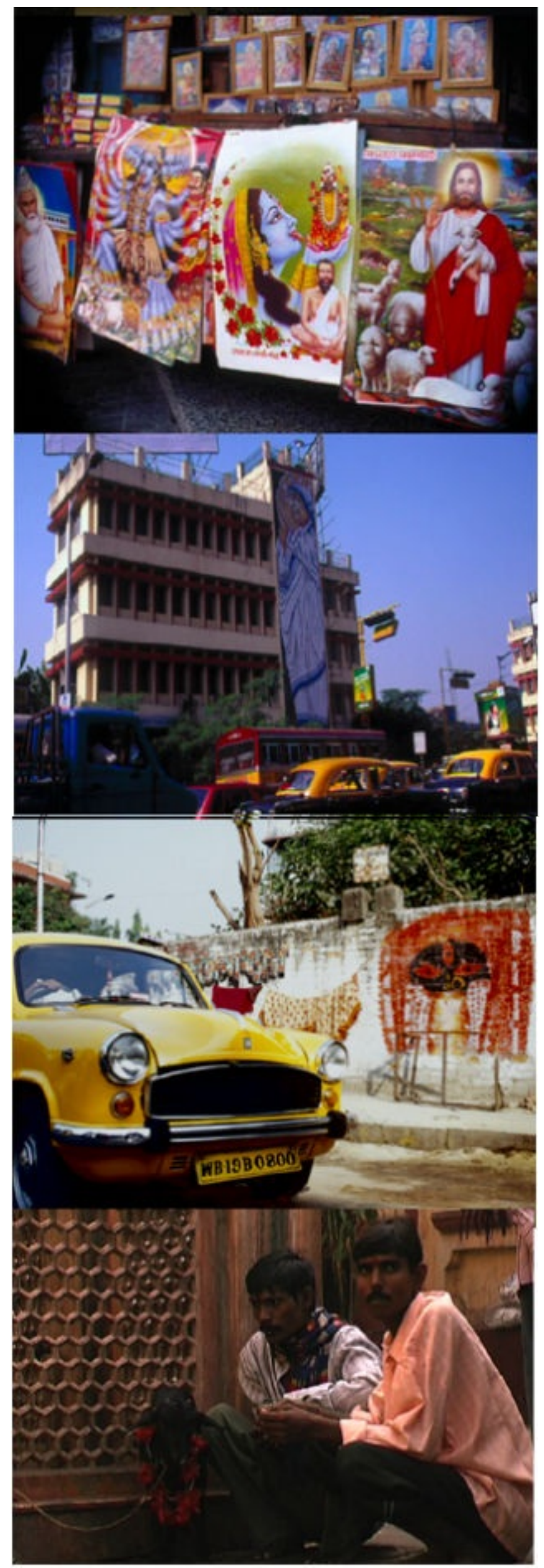

7.1 Producing images on Kali icons and recording the two main temples during the night of Kali Puja helped unveil the peculiarity of Kalighat as a historical, symbolical and cultural site in the city. Kalighat stood out in comparison with other locations for the Kali cult in the city as a place gifted for embodying particularly well the negative "Calcutta/Kali imagery" portrayed in the literary works. By narrowing the attention to Kalighat, an interesting contiguity became 
apparent: Mother Teresa's most famous centre of activity, The Hospital of the Dying, was back to back with goddess's Kali most ancient temple.

7.2 Mother Teresa's Mission was founded in 1947 and has become the most popular charity organization in the city. The Hospital of the Dying is the oldest and most famous centre of activity of the nun: it was established in rooms which belonged to Kalighat, in one of the worst neighbourhoods in the city, avoided by middle-class people for its proximity to the Red Light District of Calcutta. Why did Mother Teresa choose to establish her hospital right next to Kalighat in 1952? Although the nuns of the Mission claim that it was coincidence given a vacant area in Kalighat when Mother Teresa was looking for a site, the priests of the Kali temple give another interpretation: "Many dying people come to Kalighat to die under the eyes of Goddess Kali. Mother Teresa wanted to help the dying people as well, so this was the best place in Calcutta to find them" (Barbiani, 2002). Whether this was a conscious choice or just a coincidence is not the point: what is relevant that in 1952 the dark imagery of Calcutta starts to evolve in a new direction.

7.3 Kalighat represents a peculiar case of Kali cult, since it is the only place in the city where goat sacrifice still takes place and where the most ancient representation of the goddess is kept: if we start looking at Kali as a protective divinity, we see another religious figure right next to her, with similar qualities. It could be said that Mother Teresa occupied - symbolically and physically - the protective, maternal side of Kali, leaving the most ferocious traits of the goddess to the Kali temple. The two sides of Kali, the Protective Mother and the Destroyer, seem to be split into two places: Mother Teresa's Hospital of the Dying and the bloody ancient Kali-home (this is the meaning of the name Kalighat). Kalighat is perceived by local low-caste people as such as a unique location that they do not make a distinction between the "Kali-home" and Mother Teresa's Hospital of the Dying . Ironically, posters of Jesus with the lambs are sold side by side to images of Kali surrounded by skulls.

7.4 If Kalighat appears so significantly different from other temples of Kali around Calcutta, especially in comparison with the soothing, motherly, representation of the Kali of Dakshineswar, this may be partially related to Mother Teresa's presence in the neighbourhood. The bad reputation of Kalighat, of its temple and, in an extended sense, of Calcutta, soared in fact after 1952: the close proximity to the Hospital of the Dying, visited daily by 'western' volunteers and missionaries, made Kalighat a popular destination for religious tourism. The sacrifice of goats increased drastically to make the place more exotic for 'western' and Indian tourists alike and the temple management was taken over by a group of priests interested in gaining high profits from the flow of visitors. Erroneously, tourists take the area as the "best example of Calcutta", although local middle class people see it as the worst neighbourhood of the city. The area surrounding the Hospital of the Dying is crowded with people asking for charity, in need for medical assistance and on the verge of death. The tourists, missionaries and voluntaries who go to Kalighat see a long line of people about to die and are confronted with the screams of the goats being constantly guillotined at the temple. As can be seen from the sequence of pictures above, both the Kali presence and catholic presence are somehow caricatured in the neighbourhood: at the exit of the Kalighat metro stop a huge mosaic with Mother Teresa greets visitors, while murals are painted with the image of Kali. There are no similar murals in any other part of Calcutta.

7.5 Kalighat could well be seen as a kind of post-modern urban setting, where the icons of the two goddesses of the city compete to attract visitors by being symbolically complementary: the dark Kali and the luminous Mother Teresa are cemented as a couple in the neighbourhood. This association may have not been as strong, if goddess Kali had not been so embedded in Calcutta's religious life. It should be remembered that Kali is not just one of the many goddesses worshiped in the city, but the most important. Mother Teresa built her hospital in the heart of the city's cultural and religious centre and it is interesting to note how this particular hospital was focused on welcoming terminally ill patients and not just the sick. This particular intersection on the theme of death becomes relevant knowing Kalighat's history and Kali's symbolism. Although there are many other Mother Teresa missions around Calcutta, the Hospital of the Dying is still a favourite destination for tourists who want to see the first step of the nun's organization and, "incidentally", they have a chance to see the "worst" of Calcutta as well. If Kalighat can be seen as the place that best embodies the narrative of the "nightmarish Calcutta", where goats are slain and people come to die, it should also be noticed that a 'western' presence is (still) revealed (in new form) in its urban core $^{[6]}$ Conclusions

As the work progresses the photographer will be alert for the visual embodiment of his ideas, for images that contain and communicate the understanding he is developing. His theories will help him to photograph what he might have otherwise ignored. Simultaneously he will let what he finds in his photographs direct his theory building, the pictures and ideas becoming closer and closer approximations of one another (Becker, 1974: 15). 


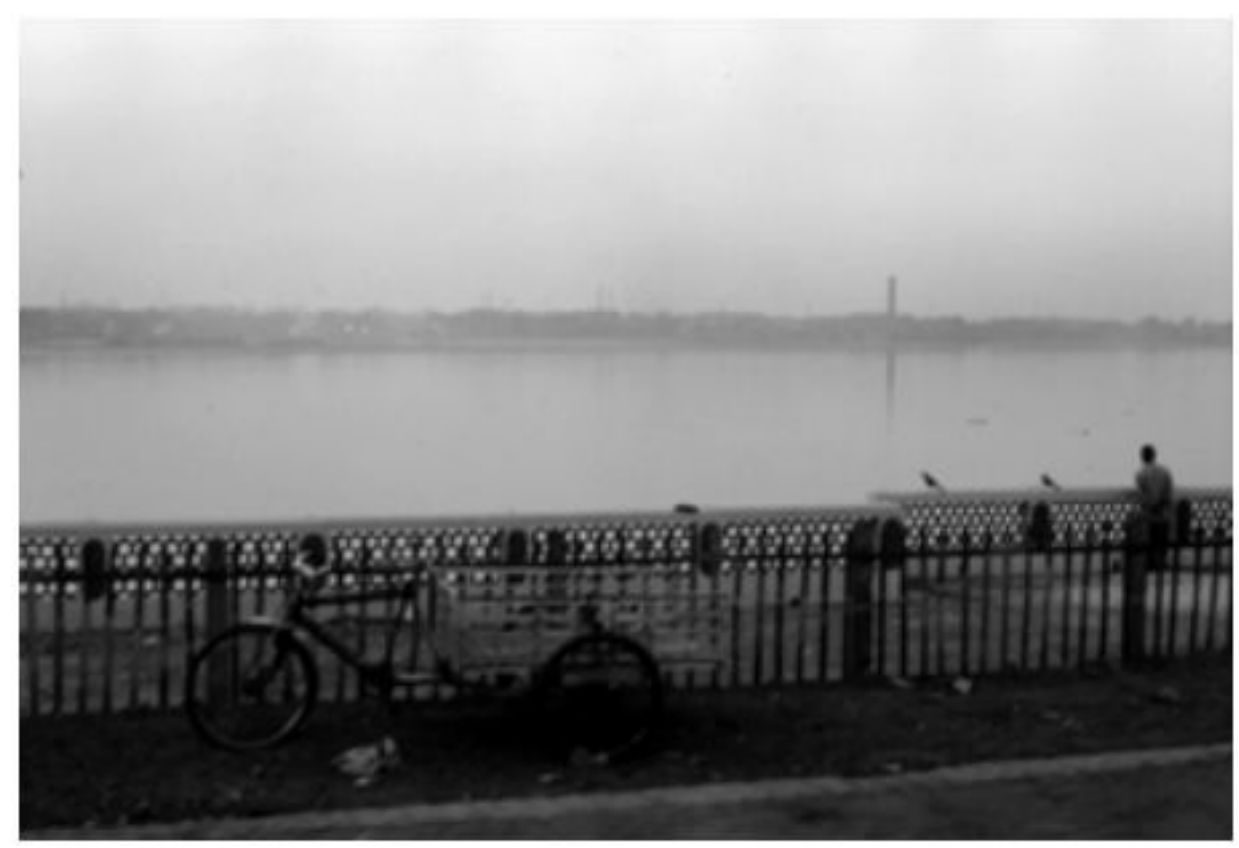

7.6 When the pictures and the ideas become "closer and closer approximations of one another" (Becker, 1974: 15), it becomes difficult to understand which came first. Was the picture taken because there was already a concept in mind or were the pictures themselves inspiring the concept? Woodwiss, (2001) argues there is no way out of this tautology: using images in social research necessarily becomes a recursive process and photographs cannot be anything more than illustrations of some aspects of social reality. My work suggests otherwise: photographic and video images are a point of access to deep connections as well as an investigative strategy. Images also have other qualities that make them a precious tool in enlivening social research: by looking for the "visual embodiments of ideas" (Becker, 1974: 15), the photographersociologist is deeply grounded in the present and in its spatial, sensory details. When a shooting script is constructed, attention is drawn to specific aspects of the subject under investigation and it may develop a relevance it did not otherwise have.

7.7 Using a still or video camera in sociological research is also similar to taking notes: but it is also more than this. Taking a picture, like writing an essay, gives relevance to the subject, or aspects of the subject, under investigation, but it is quite unlikely that all of the images will end up being significant. Selecting the pictures after they have been made is a further step in organizing their meaning. What happens, in this tautological process, is that pictures (as ideas) start to "make sense" with each other, and they acquire a meaning that is bigger than the sum of the parts. They do not only fit well in sequences, but they become "sentences" as well. The sociologist/photographer feels the need for a specific sequence of images as much as the need for a specific paragraph or sentence.

7.8 Just as words are versatile and can be used in different ways, so images also play different roles. The videos included in this paper are just a small selection of many hours of shooting. Through editing I managed to construct a sequence of images that worked with - but which cannot be simply reduced to the concepts that I wanted to convey. The edited images are not "proof" of what was happening in the two temples, but a construction focused on communicating specific concepts.

7.9 In a different, but also theoretically similar way, the two sequences of images inserted in the sections The imagery Kali/Calcutta (1.) and Kalighat/Hospital of the Dying (6.) could be considered counterparts to the written text. In the first section, images of a crowded, dirty and populated Calcutta were included, whereas the other showed the "visual signs" of the cohabitation between Kali and Mother Teresa: the murals, the mosaic, a goat about to be slain, Christ's cross at the same height of the cupola of the Kali temple. These specific illustrations are the result of a selective process, and they would not have made much sense if they had been included at the beginning of the paper.

7.10 Looking at Kalighat as a place where local and colonial culture are still constructing the negative association between goddess and city is, of course, an interpretation. But it is an interpretation that is the result of a long process of observation of different places in the city: looking at Kalighat as the location where the Kali/Calcutta narrative is embodied is a way of reading a literary metaphor in the urban space. Similar findings could have resulted from an analysis of the city's history: the early events of Calcutta's foundation are, in fact, exemplary for the further development of the symbolic importance of Kalighat. Such an analysis, however, would not have said anything useful about the role played by Kalighat today. Producing images of the two main temples of the goddess made this role relevant: it would be difficult to imagine a "Hospital of the Dying" built next to Dakshineswar. In is not a coincidence if Kalighat shocks 
'western' tourists, while Dakshineswar pleasantly impresses them. It is hard to imagine Kali as a slayer goddess by visiting the new temple of the goddess, but it is easy to be distressed by the many goats slain in the oldest abode.

7.11 What is the role of Mother Teresa in all this? The Hospital of the Dying was founded few years after Indian Independence in 1947. Compared to other Indian cities, Calcutta remained an easy destination for writers and missionaries because it was already conceived as open to a 'western' presence.

7.12 The aim of this paper is not to impute Calcutta's bad reputation to Mother Teresa's outpost, but rather to show how the Hospital of the Dying was able to fit into a symbolically rich location and thrive through it. The Kalighat neighbourhood could be seen, in a way, as a goffmanian theatre where the negative reputation of the city is being enacted and performed. Calcutta is easy to despise, because it is a known territory: by making a caricature of the negative aspects of the city, the 'west' denies its long-lasting presence in it and its deep knowledge of the city's symbolic landscape.

7.13 Making visible certain aspects of the negative reputation of the city is useful, because the imagination can open towards new views of the city's symbolic landscape. To conclude this visual exploration, there is no better way than to retread to a literary portray of Calcutta. The following quote, taken from a novel by a local author, acquires a particular meaning after this venture in Calcutta's dark symbolic landscape:

Calcutta has acquired a persona that distinguishes her from all other cities in India. It is a city of Chiaroscuro, a twilight city. It is a split psyche: both of the city and the individual. There is an uncomfortable coexistence of conflicting qualities: the tragic and the comic, the rational and the mystic, the beautiful and the ugly (Sen 1990: 50).

By looking at the city through the angle of the double, we might be able to understand better why Calcutta was, and still is, imagined twice.

\section{Notes}

1 There are many possible ethimological interpretations of the origin of the name Calcutta (Chauduri, 1990). Although it might not be the most linguistically correct, the interpretation that attributes to the goddess the origin of the city's name is the most common between local people and foreigners. This may be due to the strong assonance between Kali and Calcutta, which is even more visible in the new name taken by the city: Kolkata. As many other cities in India, such as Bombay and Madras that have changed their name into Mumbai and Chennai, Calcutta as become Kolkata to be closer to the original autochthonous pronunciation.

${ }^{2}$ Kali is frequently portrayed with blue skin, since in Hindu mythology black and blue are symbolically equivalent. They both stand for the sky, the infinite, and the void.

3 This paper is taking into account mostly how Calcutta is represented in literature, but it is important to remark that literary analysis was only one of the tools adopted: interviews, in which both western and local people were asked to talk about their imagery of the city, played an equally important role in the research project (Barbiani, 2002).

4 The other categories on which pictures were produced were: The Double Mother, Visibility of Death, Kali the Trickster, Intoxication/Pollution/Excess.

${ }^{5}$ Kalighat is both the name of the most ancient Kali temple and that of the neighbourhood where it is located. For this reason the term Kalighat carries two different meanings in this paper: the specific temple, but also its surroundings.

${ }^{6} \mathrm{~A}$ legend told by the road-dwellers in Calcutta is particularly interesting to notice how Kalighat is perceived as a meeting place between local and western culture: "The people of Calcutta wanted to build a temple in honour of Goddess Kali in the middle of a main road, but the British coloners did not want that. The British did not believe that Goddess Kali wanted a temple in Calcutta near a crossroad where an iron goat was placed. They were saying to the people of Calcutta: "Give us a proof of the sacredness of this chosen place. If you succeed in letting blood flow from this iron goat, then you will have permission to erect the temple" The people of Calcutta sent prayers to the Goddess and she appeared in the dream of a priest saying: "I will appear as an insect resting on the neck of the goat. Place the blade on the point where I will be laying and blood will flow out of the iron goat. When the sahibs circled around the goat an insect laid on it and the priest placed the blade on that point: blood flew out and the British had to admit that the place was sacred. The British commander, riding his horse, started to trace a large square around the sacred 
goat and the ground touched by the horse's hooves became the perimeter of the sacred Kali temple".

\section{References}

BARBIANI, E. 2002. Kali e Calcutta: immagini della dea, immagini della metropoli . Urbino: University of Urbino.

BECKER, H. 1974. "Photography and Sociology". Studies in the Anthropology of Visual Communication" vol.1, n.1.

CHAUDHURI. 1990. Calcutta: the living City. Volume I: The Past. London: Oxford University Press.

GRASS, Gunter. 1988. Show your Tongue. New York: Harvest Books.

GRISWOLD, W. 1994. Cultures and Societies in a Changing World. London: Sage.

HANNERZ, U. 1983. Exploring the City: Inquiries toward an Urban Anthropology . New York: Columbia University Press.

HARPER, D. 1988. "Visual Sociology: Expanding Sociological Vision", The American Sociologist, Spring: 54-70.

KIPLING. 1890. The City of Dreadful Night . London: International Law and Taxation.

LASH S. and Urry J. 1994. Economies of Signs \& Space, London: Sage.

LAPIERRE, D. 1984. The City Of Joy, New York: Mass Market Paper Back edition.

LYNCH, K. 1960. The Image of the City. Cambridge: MIT Press.

MOORHOUSE, J. 1971. Calcutta: the city revealed. New Delhi: Pinguin Books India.

PROSSER, Jhon. 1998. Imaged-based Research: a sourcebook for Qualitative Researchers, London: Routledge Falmer.

SALGARI, E. 1954. I misteri della giungla nera. Torino: Einaudi.

Sen, G. 1990. The Calcutta Psyche. New Delhi: The India International Centre.

SIMMONS, D. 1985. The Song Of Kali . New York: Bluejay Books

SWAMI JAGADISWARANANDA. 1953. Devi Mahatmyam. Madras: Sri Ramakrishna Math.

SUCHAR, 1997. C. Grounding Sociological Research in Shooting Scripts. Qualitative Sociology. Vol. 20. n.1.

WOODWISS, 2001. The Visual in Social Theory. New York: The Athlone Press. 